\title{
Siðferðisbrot og kristinn mannskilningur
}

Fyrir tíu árum birtist grein par sem sjónum var beint að gerendum kynferðislegs ofbeldis og áreitis á kirkjulegum vettvangi og lutu spurningar greinarinnar meðal annars að pví hver væri guðfræðileg og siðfræðileg afstaða og boðskapur kirkjunnar til peirra. ${ }^{1}$ Með skírskotun í págildandi starfsreglur íslensku pjóðkirkjunnar (nr. 739/1998) var á pað bent að kirkjan hefði siðferðilegum skyldum að gegna gagnvart meintum gerendum slíkra brota og vísað í texta starfsreglnanna pví til stuðnings en par sagði m.a.: „Kirkjuleg yfirvöld skulu sjá til pess að sálgæsla verði veitt meintum geranda, fjölskyldu hans og peim sem í kirkjulegu starfi hafa verið í mikilvægu samstarfi við hann. Æskilegt er að sálgæsla pessi sé veitt af presti î heimahéraði, innan sóknar eða prófastsdæmum."2 Hvernig kirkjulegri sálgæslu hefur raunverulega verið háttað gagnvart gerendum kynferðisbrota og fjölskyldum peirra á umliðnum árum er ekki umræðuefni pessarar greinar en til pess hefði purft annars konar nálgun. Sjónum er hér strangt til tekið hvorki beint að gerendum né polendum kynferðisofbeldis í pröngri merkingu, né heldur kynferðisbrotum presta og annarra vígðra pjóna kirkjunnar og ekki er heldur að pví spurt hvernig kirkjan víða um heim hafi tekist á við pau.

Markmið greinarinnar er mun hógværara og felur tvennt í sér. Annars vegar pað að varpa ljósi á eðli siðferðisbrota en til að gera pað styðst ég við siðfræðilega orðræðu. Par ber hæst hugtök eins og virðing fyrir manneskjunni, sjálfræði og mannhelgi. Síðara markmiðið er að draga fram kjarna kristins mannskilnings sem pann grundvöll sem kirkjan stendur á í allri umræðu um siðferðisbrot. Í peirri umræðu leika hugtökin sekt, skömm, synd og ábyrgð mikilvægt hlutverk.

Í upphafi er rétt að nefna kristna guðsmynd og leggja áherslu á réttlæti Guðs, náð, miskunn og kærleika. ${ }^{3}$ Réttlæti og kærleikur eru burðarhugtök í kristinni siðfræðilegri framsetningu og priðja hugtakið, náðin, er óumdeilanlega eitt mikilvægasta hugtak lútherskrar siðbótar. Kjarnahugmynd kristins mannskilnings er mannhelgin en pað hugtak sækir næringu til vestrænnar heimspeki og guðfræði. Pegar talað er um kristinn mannskilning er lögð áhersla á synd og breyskleika mannsins 1 brotnum heimi en jafnframt náð Guðs og miskunn ásamt kærleika og réttlæti til handa peim sem iðrast gerða sinna. Í hnotskurn, má pví orða pað svo að áherslan í greininni liggi

\footnotetext{
1 Sólveig Anna Bóasdóttir, „Kirkjan og kynferðisofbeldi: Gerendur kynferðislegs ofbeldis — frá guðfræðilegu og siðfræðilegu sjónarhorni“, Ritröð Guðfraðistofnunar, 31/2010, bls. 144-161.

2 Hlekkur á pessar starfsreglur er ekki lengur virkur par sem pær eru aflagðar. Ný stefna pjóðkirkjunnar um sambærileg mál, sem sampykkt var með ályktun á kirkjupingi 2018, hefur leyst pær af hólmi, sótt 10. febrúar 2020 af slóðinni: https://kirkjan.is/library/Files/Starfsreglur/Stefna \%20\%C3\%BEj\%C3\%B3\%C3\%B0kirkjunnar\%20um\%20a\%C3\% B0ger $\%$ C3\%B0ir $\% 20$ gegn $\% 20$ einelti $\% 20$ kynfer $\%$ C3\%B0islegri $\% 20 \% \mathrm{C} 3 \% \mathrm{~A} 1$ reitni $\% 20$ kynbundinni $\% 20 \% \mathrm{C} 3 \% \mathrm{~A} 1$ reit

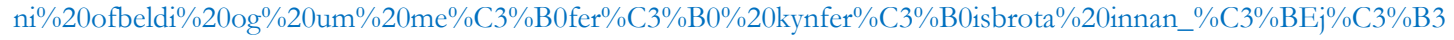
$\%$ C3\%B0kirkjunnar.pdf.

${ }^{3}$ Kærleikur og miskunn Guðs eru í guðfræðilegri orðræðu tvær hliðar á sömu mynt. Kærleikur Guðs felur alltaf í sér miskunn hans. Ég nota hugtökin jöfnum höndum í greininni.
} 
á guðfræðilegri og siðfræðilegri túlkun á kristnum mannskilningi og mikilvægi hans í umræðu um siðferðisbrot.

Nýverið hefur íslenska pjóðkirkjan lagt sig fram um að efla velferð polenda í siðferðisbrotamálum og er pað er vel. ${ }^{4}$ Kristur fór ekki í manngreinarálit og pað gerir kirkjan ekki heldur. Hún má pví ekki láta undir höfuð leggjast að mæta gerendum siðferðisbrota af virðingu með pað að markmiði að peir horfist í augu við breytni sína og taki ábyrgð á henni. Greinin skiptist í tvo hluta. Í peim fyrri verður sjónum beint að hugtakinu siðferðisbrot en í peim síðari verður kristinn mannskilningur í kastljósinu. Byrjum á að skoða hugtakið siðferðisbrot.

\title{
Siðferðisbrot
}

Hvað felst í siðferðisbroti? Er til skýr skilgreining á pessu hugtaki? Svo að byrjað sé á að vísa til kirkjulegs samhengis pá kemur hugtakið siðferðisbrot fyrir í12. grein laga um stöðu, stjórn og starfshætti pjóðkirkjunnar. ${ }^{5}$ Hugtakið er bó hvergi skilgreint 1 í peim lögum en í fyrstu málgrein 12. greinar laganna má finna eftirfarandi setningu: „Nú rís ágreiningur á kirkjulegum vettvangi eða starfsmaður pjóðkirkjunnar er borinn sökum um siðferðis- eða agabrot og getur pá hver sá sem hagsmuna á að gæta borið málið undir úrskurðarnefnd sem biskup Íslands skipar til fjögurra ára í senn.“ Af pessari grein er ljóst að pað kemur í hlut úrskurðarnefndar kirkjunnar hverju sinni að meta hvers konar hegðun flokkast sem siðferðisbrot eða agabrot. Dæmi um slíka túlkun má finna í nýlegum úrskurði úrskurðarnefndar kirkjunnar en par segir að:

\begin{abstract}
... hugtakið siðferðisbrot hafi mjög óljósa merkingu í lagamáli. Ganga megi að pví vísu að siðferðisbrot purfi ekki að vera refsivert brot að lögum, jafnvel ekki neins konar réttarbrot. Siðferðisbrot purfi ekki heldur að vera svívirðilegt að almenningsáliti. Rétt sé að miða við eins konar vísireglu, er veiti úrskurðaraðilum svigrúm til pess að móta og ákvarða eftir siðferðislegum og félagslegum mælikvarða á hverjum tíma, hvað sé siðferðisbrot. Í pví efni skipti verulegu máli hver staða starfsmannsins er og við hvaða aðstæður hin umdeildu atvik gerast. Almennt verði að gera strangar kröfur til [...] pjóðkirkjunnar um að gæta hófsemi og velsæmis i störfum sínum og hafa í huga virðingu peirrar stofnunar, sem peir starfa hjá eða eru i fyrirsvari fyrir. Баð er mat úrskurðarnefndar að kynbundið ofbeldi, kynbundin áreitni og kynferðisleg áreitni hljóti alltaf að teljast siðferðisbrot skv. 12 gr. pjóðkirkjulaga. ${ }^{6}$
\end{abstract}

pessi texti úrskurðarnefndar kirkjunnar árið 2018 er um margt upplýsandi varðandi umfjöllunarefni mitt. Til að byrja með má benda á hið augljósa, p.e. að siðferðisbrot feli í sér hegðun sem tjái vanvirðingu eða lítilsvirðingu gagnvart manneskju. Forsenda siðadóms er siðferðileg sýn á manneskjuna og gildi hennar. Pá sýn mætti t.d. orða svo: Manneskjan er einstök og dýrmæt vera. Líf hennar hefur sjálfstæett gildi og pví má ekki sýna henni lítilsvirðandi framkomu. ${ }^{7}$ En lítum nú nánar á textann hér að

\footnotetext{
${ }^{4}$ Dæmi um pað má finna í yfirlýsingu priggja biskupa kirkjunnar: „Til polenda: Yfirlýsing vegna siðferðisbrota“, sótt 10. maí 2020 af https://kirkjan.is/library/Files/utgafa/BAeklingar/Til\%20\%C3\%BEolenda\%20$\% 20$ yfir $1 \%$ C3 $\%$ BDsing $\% 20$ vegna $\% 20$ si $\%$ C3 $\%$ B0fer $\%$ C3 $\%$ B0isbrota $\% 20 \%$ C3 $\% 931$ afs $\% 20 J \% C 3 \%$ B 3 hannssonar.pdf. Óhætt er að fullyrða að allt frá pví að rannsóknarnefnd kirkjupings sendi frá sér skýrslu um viðbrögð og starfshætti pjóðkirkjunnar vegna ásakana á hendur Ólafi Skúlasyni biskupi um kynferðisbrot árið 2011 hafi kirkjan markmisst reynt að bæta vinnu sína og viðbrögð í pessum málaflokki. Skeýrsla um viðbrögð og starfshatti pjóðkirkjunnar vegna ásakana á bendur Ólafi Skúlasyni biskupi um kynferdisbrot, Reykjavík: án útg., 2011.

${ }^{5}$ Lög um stöðu, stjórn og starfshætti pjóðkirkjunnar nr. 78/1997, sótt 10. maí 2020 af https://www.althingi.is/lagas/nuna/1997078.html.

${ }^{6}$ Dessi úrskurður er frá árinu 2018 og var kveðinn upp í máli nr. 4/2017, sótt 10. maí 2020 af https://kirkjan.is/library/Files/4-2017-0C3\%BArskur\%C3\%B0ur\%2027.\%20febr\%C3\%BAar\%202018nafnhreinsa $\%$ C $3 \%$ B0ur.pdf.

7 Dessi sýn á manneskjuna fær stuðning i 3. grein Mannréttindayfirlýsingu Sameinuðu pjóðanna en par stendur: „Allir eiga rétt til lífs, frelsis og mannhelgi““.
} 
framan. Í fyrsta lagi er par lögð sérstök áhersla á pað sem áður var nefnt, að pað sé túlkunar- og matsatriði hvað sé siðferðisbrot og hvað ekki. Í öðru lagi er á pað bent að siðferðisbrot purfi ekki (endilega) að vera lögbrot né séu pau heldur alltaf mjög gróf (les: svívirðileg). Í priðja lagi er undirstrikað að líta purfi til innbyrðis valdastöðu peirra sem málið varðar, p.e. peirra sem telja á sér brotið siðferðilega og peirra sem ásakaðir eru um siðferðisbrot. Loks telur úrskurðarnefndin greinilega ástæðu til að undirstrika pað аð kynbundið ofbeldi, kynbundin áreitni og kynferðisleg áreitni séu alltaf siðferðisbrot í skilningi pjóðkirkjulaganna.

Ég vil byrja á að staldra við priðja atriðið í textanum hér að framan og benda á að pað er ekkert óeðlilegt við ójafna valdastöðu milli fólks almennt og yfirleitt. Vald í merkingunni gögn og gæði er breytilegt fyrirbæri. Sama manneskjan hefur oft margs konar hlutverk með höndum í samfélaginu og er pví ýmist gerandi/skapandi eða polandi/skynjandi í mismunandi aðstæðum. ${ }^{8}$ Enginn er pannig alltaf ,gerandi“ eða alltaf „polandi“ heldur fer pað ekki síst eftir valdastöðu viðkomandi hverju sinni. Undantekning frá pessu eru börn. Staða peirra sem slík er alltaf viðkvæm pegar kemur að valdi. Hér eru börn pó ekki til umræðu heldur fullorðið fólk. Vandamál sem tengjast valdi í slíkum tilvikum koma upp pegar einstaklingar sem gegna ábyrgðarstöðu í samfélaginu eru ekki nægjanlega meðvitaðir um pá ábyrgð og skyldur sem fylgja peirri ákveðnu stöðu. Eitt einkenni siðmenningar er að fólk skiptir með sér verkum, en slík (hlut)verkaskipting hefur рað að markmiði að við öll getum notið betra lífs, skrifar Sigurður Kristinsson heimspekingur og bætir við: „Фar með er ljóst að sá sem stundar sérhæft starf ber ábyrgð gagnvart hinu verkskipta samfélagi í heild sinni. “9 Detta eru ekki ný sannindi. Баð sem Sigurður áréttar er einfaldlega pað að sem manneskjur erum við alltaf siðferðisverur og berum ábyrgð sem slíkar gagnvart samfélagi okkar. Í sérhæfðum störfum okkar höfum við auk pess sérstökum starfsskyldum að gegna og í vissum tilvikum skortir upp á meðvitund um hverjar pær eru og hvað pær pýða. ${ }^{10}$

Баð er mannlegt að mistakast. Með pví er ég ekki að gera lítið úr siðferðisbrotum. Páll Skúlason heimspekingur komst á einum stað pannig að orði um siðferðið að pað væri „,brennimerkt af skammsýni““. „Okkur skjátlast iðulega um pað sem raunverulega skiptir okkur máli, vegna pess hve sjóndeildarhringur okkar er takmarkaður",11 skrifar hann. Hér er tekið undir pað og bent á hin ævafornu sannindi, að manneskjan sé breysk. Við gerum skyssur og misstígum okkur. Við erum ekki nógu næm, lesum ekki aðstæður rétt og par fram eftir götunum. Aðalatriðið pegar slíkt gerist er að kannast við pað, horfast í augu við ófullkomleika sinn, biðjast einlæglega afsökunar, reyna að læra af reynslunni og bæta fyrir brot sín. „Að proskast sem siðferðisvera felur í sér að manni lærist smám saman að sigrast á eigin skammsýni án pess pó að

\footnotetext{
8 Detta orðalag sæki ég til Páls Skúlasonar pegar hann lýsir okkur mönnum sem lífverum. Hann skrifar: „Sérhver lífvera hefur tvær hliðar. Hún er annars vegar polandi (skynjandi), hins vegar skapandi (gerandi). Sem polandi tekur hún á móti áhrifum, verður fyrir alls kyns áreiti og nemur boð frá umhverfi sínu. Sem skapandi hefur hún áhrif á umhverfi sitt, gerir eitt og annað og sendir frá sér boð.“" Siðfrađi: Um erfiðleika i sidfferđi og forsendur ákvardana, Reykjavík: Rannsóknarstofnun í siðfræði, 1990, bls. 20.

9 Sigurður Kristinsson, Siðareglur, Reykjavík: Rannsóknarstofnun í siðfræði, Háskóli Íslands, 1991, bls. 17.

${ }^{10}$ Sigurður Kristinsson, Siðareglur, bls. 19.

11 Páll Skúlason, Sidfraodi. bls. 21.
} 
hún verði nokkurn tíma úr sögunni““, 12 skrifar Páll Skúlason. Sú túlkun hans á siðferðinu rímar við skoðun mína og fellur auk pess vel að kjarna klassísks, kristins mannskilnings eins og betur verður komið að síðar í greininni.

Hitt atriðið sem ég vil nefna og kom fram í áðurnefndum texta úrskurðarnefndar kirkjunnar (2018) er pað að siðferðisbrot varða langt pví frá alltaf við lög. Viðskeytið „brot“ í orðinu siðferðisbrot beinir pó huganum oftar en ekki inn á svið lögfræði, að ég ekki segi lögtækni. Lögfræðingar eru ekki sérfræðingar í siðferðismálum og pað er reyndar enginn ef pví er að skipta. Ályktunin sem ég vil draga að svo komnu máli er pví sú að fyrir utan proskaleysi, dómgreindar- eða reynsluleysi verða aðstæður og alls kyns klaufaskapur til pess að siðferðisbrot eiga sér stað jafn oft og raun ber vitni. Detta er nauðsynlegt að viðurkenna sem eina af staðreyndum lífsins og hluta mannlegrar reynslu. Par með er ekki hægt að setja punkt heldur krefst pessi staðreynd pess að við tökum á slíkum málum af ábyrgð hverju sinni.

\section{Virðing fyrir manneskjunni, sjálfræði og mannhelgi}

Siðfræðilegu hugtökin virðing fyrir manneskjunni, sjálfræði og mannhelgi geta aukið við skilninginn á pví hversu alvarleg siðferðisbrot geta verið. ${ }^{13}$ Byrjum á að spyrja hvað hugmyndin ${ }^{14}$ um virðingu fyrir manneskjunni felur í sér? Svar Vilhjálms Árnasonar heimspekings er á pá leið að virðingarhugsjónin sé ein pýðingarmesta hugmynd vestrænnar menningar en um leið sé hún meðal peirra sem sé hvað erfiðast að fylgja eftir. Kjarninn lúti að siðferðilegum jöfnuði og pví „[a]ð allar manneskjur fái að lifa pannig að verðleikar peirra og einstaklingseðli geti notið sín“.15 Sé hugmyndin skilin pannig tjái hún jafnframt sjálfstætt og einstakt gildi manneskjunnar og pegar petta sé leitt til öndvegis sé hugmyndin ótrúlega öflug og hafi burði til pess að vera grundvöllur hvers konar gagnrýni á meiðandi og niðurlægjandi framkomu gagnvart manneskjunni. Vilhjálmur kemst svo að orði: „Höfuðástæða pess að okkur ber að auðsýna fólki virðingu er að manneskjan er vera sem er fær um að meta eigin athafnir og finna lífi sínu pann farveg sem hún sjálf telur mikilvægan“. ${ }^{16}$ Hér nálgumst við sjálfræðishugmyndina en ekki bara pað heldur einnig kjarna manngildishugsjónarinnar. Sé skyggnst dýpra í túlkun Vilhjálms á virðingu manneskjunnar kemur meira í ljós. Manneskjan er andleg vera. Hún á sér sálarlíf og sjálfsvitund. Hún er sjálfsvera en ekki hlutvera, sem merkir að pað megi ekki ráðskast með hana án vitundar hennar og vilja. Hún býr yfir sjálfræði og dómgreind til að meta réttmæti eigin athafna en segja má að allir pessir eiginleikar samanteknir feli mennskuna í sér. ${ }^{17}$ Krafan um að sýna manneskjunni virðingu snýst pó ekki um undirgefni af neinu tagi heldur mun fremur um að „taka hennar eigið verðmætamat og sjónarhorn á lífið alvarlega“, skrifar Vilhjálmur. Til að skilja petta betur skulum við einbeita okkur að sjálfræðishugmyndinni en hún er samofin ofangreindri túlkun á virðingu fyrir manneskjunni!

\footnotetext{
12 Páll Skúlason, Sidfreði, bls. 21.

13 Vilhjálmur Árnason, Siðfraði lifs og dauða: Erfiðar ákvardanir i heilbrigðispjónustu, 2. útgáfa, aukin og endurbætt, Reykjavík: Siðfrææistofnun og Háskólaútgáfan, 2003. Hér verður látið nægja að vísa í texta Vilhjálms, en ekki í pá texta sem hann vísar til. Í framhaldinu verður hér byggt á pessum skrifum Vilhjálms sem fyrir sitt leyti styðst við skrif pekktra heimspekinga, par á meðal pýska heimspekingsins Immanúels Kants.

${ }^{14}$ Vilhjálmur lítur svo á að hugmyndin sé jafnframt hugsjón.

15 Vilhjálmur Árnason, Siðfraði lifs og dauda, bls. 22.

16 Vilhjálmur Árnason, Sidfraði lifs og dauda, bls. 22-23.

17 Vilhjálmur Árnason, Siðfreði lifs og dauda, bls. 23.
} 
Hvert er pá vægi hennar og hvernig tengist hún virðingunni fyrir manneskjunni nánar tiltekið?

Vilhjálmur segir sjálfræði vera eitt megingildi mannlegrar tilveru. Ьað sem einkennir manneskjuna og markar henni sérstöðu, skrifar hann, er að hún er viljavera með hæfileika til athafna, ákvarðana og vals. Vilhjálmur dýpkar túlkun sína með pessum orðum:

\begin{abstract}
Баð er petta sem átt er við pegar sagt er að manneskjan sé sjálfsvera, pað er gerandi með sjálfsvitund og sjálfsmynd. Hún er vera með langanir og vilja, gildismat og tilfinningar sem hafa áhrif á pað hvaða stefnu líf hennar tekur. Manneskjan er pví aldrei einber polandi atburða og aðstæðna; hún bregst við peim og gefur peim merkingu og mikilvægi sem eru til marks um lífsáform hennar og veruleikasýn. Pótt pessi viðbrögð séu mótuð bæði af persónulegri sögu og af peirri menningu sem manneskjan er sprottin úr, pá eru pau hennar eigin svör við peim spurningum sem aðstæðurnar vekja. ${ }^{18}$
\end{abstract}

Augljóslega má segja að sjálfræðið snúi að hinum sjálfstæða tilgangi sem sérhver manneskja hefur með lífi sínu. Manneskja hefur efni til að proska með sér sjálfstæðan vilja sem ber að virða svo lengi sem henni er sjálfrátt. Siðferðilegt sjálfræði tengist pannig viljanum órofa böndum. Vilhjálmur skrifar: „Við ráðleggjum oft einstaklingum og leggjum jafnvel hart að peim að fá pá til að gera pað sem við teljum að sé peim til góðs, en á endanum verðum við að virða eigin ákvörðun fullveðja fólks. “19 Раð gerum við með ýmsum hætti, t.d. með pví að halda að okkur höndum, halda okkur í vissri fjarlægð. Við skyldum ekki taka ráðin af fullveðja fólki skrifar Vilhjálmur pegar hann fjallar um petta atriði í skrifum sínum og heldur áfram:

Hver manneskja verður að fá svigrúm til að finna lífi sínu takmark og tilgang. Hér er um pað að ræða аð virða mannhelgi einstaklings, en hana má hugsa sér líkt og landhelgi, p.e. sem pað „rými“ sem persónan á óskoraðan umráðarétt yfir. Рað er einkenni á eigingjörnu og tillitslausu fólki að pað virðir ekki pess mannhelgi, pví að pað pekkir hvorki eigin „mörk“ né annarra. ${ }^{20}$

Dessi lýsing virðast mér falla vel að pví sem hér er verið að brjóta til mergjar, pað er eðli siðferðisbrota. Ein leið til að lýsa siðferðisbroti er pá að segja að farið hafi verið yfir persónuleg mörk annarrar manneskju að henni forspurðri. Vilhjálmur kemur með samlíkinguna milli mannhelgi og landhelgi og leggur til að við skiljum hugtökin rýmisskilningi. Раð rými sem sé innan landhelginnar sé eigið, persónulegt svæði einstaklingsins sem enginn hafi rétt til að athafna sig á, án samráðs. Einstaklingurinn á pá samkvæmt pessu, skilyrðislausan „umráðarétt“ yfir pessu svæði en pann rétt kallar Vilhjálmur „griðarétt" til aðgreiningar frá hugtakinu „gæðarétti“. Persónulegt „griðland“ merkir pað sama og „friðland“. Раð er með öðrum orðum hið persónulega rými sem einstaklingurinn parfnast til að geta verið „,hann sjálfur“ eða „hún sjálf“ 1 merkingunni „mótað athafnir sínar og hugsanir í samræmi við eigin vilja og verðmætamat.“21 Pegar úrskurðarnefnd pjóðkirkjunnar komst að pví árið 2018 að „kynbundið ofbeldi, kynbundin áreitni og kynferðisleg áreitni hljóti alltaf að teljast siðferðisbrot skv. 12 gr. pjóðkirkjulaga“ pá má túlka pað sem svo að hún hafi skilið siðferðið eins og Vilhjálmur Árnason gerir hér að framan. Pegar farið er yfir persónuleg mörk manneskju, líkamlega, andlega eða kynferðislega, án samráðs, kallast pað siðferðisbrot.

\footnotetext{
18 Vilhjálmur Árnason, „Sjálfræði í aðstæðum aldraðra“, Sjálfraði og aldraðir: Í ljósi íslenskera aðstaðna, ritstj. Ástríður Stefánsdóttir og Vilhjálmur Árnason, Reykjavík: Siðfræðistofnun og Háskólaútgáfan, 2004, bls. 13-35, hér 13.

${ }^{19}$ Vilhjálmur Árnason, Sidfraði lifs og dauða, bls. 24.

${ }^{20}$ Sama heimild, bls. 24.

${ }^{21}$ Vilhjálmur Árnason, Broddflugur: Sidferdilegar ádeilur og samfélagsgagnrýni, Reykjavík: Háskólaútgáfan, 1997, bls. 250-251.
} 
Hver er pá niðurstaðan pegar hér er komið sögu? Svar mitt er að kjarnahugtök siðfræðilegrar orðræðu veiti innsýn í eðli siðferðisins og par með eðli siðferðisbrota. „Sá sem rannsakar siðferðið kemst ekki hjá pví að taka afstöðu til pess og leggja mat á kosti pess og lesti“, skrifaði Páll Skúlason á einum stað. ${ }^{22}$ Dví er ég sammála. Með pví að rannsaka siðferðið skoðum við jafnframt samfélagið og okkur sjálf. Ekkert samfélag fær staðist án siðferðis. Siðferðisbrot veikja ekki aðeins pær persónur sem brotið hefur verið á heldur einnig samfélagið allt. Við verðum að nálgast siðferðisbrot í samfélaginu af ábyrgð. Kastljósinu skyldi ekki einvörðungu beint að einstaklingssekt eða hugsanlegri ákæru og skaðabótum. Мeð pess konar ábyrgð er horft til baka og er til pess fallin að einangra gerandann frá samfélaginu. Рað ábyrgðarhugtak sem ég sé fyrir mér, lítur ekki síður til framtíðar og krefur okkur um gagnrýna hugsun varðandi manninn og eðli hans. Auðvitað parf að gaumgæfa og grandskoða pað siðferðisbrot sem átti sér stað en jafnframt parf að draga lærdóma af pví til framtíðar. Gerandinn er einn af okkur. Við erum eins og hann. Við byggjum sama samfélag og hann, deilum viðmiðum pess með honum, reynslu og draumum. Pessi túlkun er mikilvægt framlag kristins mannskilnings til pess verkefnis og jafnframt umfjöllunarefni síðari hluta greinarinnar.

\section{Siðferðisbrot á kirkjulegum vettvangi}

Pegar manneskja í pjónustu kirkjunnar er ásökuð um siðferðisbrot á kirkjulegum vettvangi og víðar er pað alvanalegt að hún upplifi pað sem gerðist á allt annan hátt en sá/sú sem fyrir atvikinu varð. ${ }^{23}$ Mikilvægt er í slíkum aðstæðum, segir Marie Fortune sem hefur víðtæka reynslu af slíku, að taka sér fyrst stöðu með persónunni sem upplifir siðferðisbrot og hlusta á lýsingu viðkomandi á pví sem átti sér stað. ${ }^{24}$ Jesús var sér pess fyllilega meðvitaður að fylgjendur hans, líkt og aðrir, væru ófullkomnar manneskjur sem gætu villst af réttri leið. Viðbrögð hans við peirri staðreynd voru pau að sérhver sem brýtur gegn siðferðinu verði að horfast í augu við gjörðir sínar og iðrast. Pannig var iðrun undanfari fyrirgefningar, samanber orð Jesú í Lúkasarguðspjalli: „Hafið gát á sjálfum yður. Ef bróðir pinn syndgar, pá ávíta hann og ef hann sér að sér, pá fyrirgef honum. Og pótt hann misgeri við pig sjö sinnum á dag og snúi sjö sinnum aftur til pín og segi: Ég iðrast, pá skalt pú fyrirgefa honum“ (Lúk 17.3-4).

Svo að áfram sé byggt á pekkingu Marie Fortune á viðbrögðum gerenda pá er pað reynsla hennar að peir sem brjóti gegn siðferðinu dragi yfirleitt úr, neiti og jafnvel ljúgi til um pað sem hafi átt sér stað. Рað sé sjaldgæft að peir láti í ljós iðrun vegna gjörða sinna eða álíti pær rangar. Fremur en að blygðast sín fyrir pann skaða sem peir hafi valdið, reiðist peir öðrum og hafi áhyggjur af orðspori sínu. ${ }^{25}$ Dessi lýsing hljómar vissulega sem afar neikvæð en pó er nauðsynlegt að hafa hana í huga. Aðalatriði hér er pað sem nefnt var hér að framan: að kalla skuli pá til ábyrgðar sem brjóta gegn siðferðinu og mun ég leitast við að fjalla nánar um hvað felst í pví með tilvísunum í kristinn mann- og syndaskilning.

\footnotetext{
22 Páll Skúlason, Siðfraði, bls. 62.

${ }_{23}$ Marie M. Fortune, Sexual Violence: The Sin Revisited, Cleveland: The Pilgrim Press, 2005.

${ }^{24}$ Sama heimild, bls. 110-123.

${ }^{25}$ Sama heimild, bls. 200-201.
} 
Samkvæmt kristnum trúarskilningi samanstendur kristinn söfnuður og samfélag af syndugu fólki en jafnframt fólki sem Guð fyrirgefur allar syndir. Kirkjan er söfnuður hinna heilögu og réttlættu, jafnframt pví sem hún er syndug og breysk. Pessi syndaskilningur er boðaður í sérhverri guðspjónustu og er samofinn kristnum boðskap og par með hluti kristins mannskilnings. Við tökum undir hann pegar við förum með hina ævafornu syndajátningu kristinnar kirkju: „Ég játa fyrir pér, almáttugi Guð, skapari minn og lausnari, að ég hef margvíslega syndgað í hugsunum, orðum og gjörðum. Fyrirgef mér sakir miskunnar pinnar og leið mig til eilífs lífs, til dýrðar nafni pínu“.

Samkvæmt skilningi Lúthers er náðin og miskunnin virk í gegnum starf heilags anda 1 heiminum. Öll höfum við syndgað og lifum pví í skugga syndar. Samtímis lifum við undir náðarsól Guðs sem aldrei víkur frá okkur. ${ }^{26}$ Pótt syndin vofi ætíð yfir er náðin sterkari og hún megnar að réttlæta manninn fullkomlega frammi fyrir Guði. Náð Guðs kemur ekki í smáskömmtum, að mati Lúthers, heldur umfaðmar hún okkur á bak og brjóst. Рað megum við pakka Kristi fyrir, meðalgöngumanninum sem biður okkur náðar. ${ }^{27}$ Grundvöllur pess að hægt sé að tala um ábyrgð í pví samhengi sem hér er til umræou er pví kristinn mannskilningur, p.e. mannskilningur par sem ófullkomleiki og réttlæti manneskjunnar í senn er undirstrikað. Pennan boðskap um manninn hafa fáir sett betur fram en einmitt Lúther! Afleiðingar pessa boðskapar eru raunverulegar í samfélaginu en pær ganga út á pað að engan syndara sem iðrast og viðurkennir brot sín má útiloka frá náð Guðs og kirkju hér á jörð. Vegna réttlætis Guðs og miskunnar býðst hinni ófullkomnu manneskju fyrirgefning, að pví gefnu að hún snúi frá villu síns vegar og iðrist af heilu hjarta, samanber orð Esekíels spámanns: „Snúið við, hverfið frá öllum afbrotum ykkar svo að pau verði ykkur ekki að falli. Varpið frá ykkur öllum peim afbrotum sem pið hafið framið. Fáið ykkur nýtt hjarta og nýjan anda“" (Esk 18.30-31).

Næsta stig hinnar guðfræðilegu umræðu um manninn er pað að viðurkenning á synd mannsins felur jafnframt í sér viðurkenningu á ábyrgð hans. Ábyrgðarhugmyndin er nátengd hugmyndinni um mannhelgina en guðfræðingum er tamt að halda fram virðingunni fyrir manneðlinu með pví að benda á guðslíkingarhugmyndina í Fyrstu Mósebók par sem segir um manninn að hann beri mynd Guðs, skapara síns:

\footnotetext{
Pá sagði Guð: „Vér viljum gera manninn eftir vorri mynd, líkan oss. Hann skal drottna yfir fiskum sjávarins, fuglum loftsins, búfénu, villidýrunum og allri jörðinni og öllum skriðdýrum sem skríða á jörðinni.“ Og Guð skapaði manninn eftir sinni mynd. Hann skapaði hann eftir Guðs mynd. Hann skapaði pau karl og konu. (1Mós 1. 26-27)
}

Hér getur að líta kjarnahugmynd mannhelginnar í kristnu og guðfræðilegu samhengi. Samkvæmt henni er maðurinn skapaður eftir Guðs mynd. Líf mannsins er gjöf. Tilvist mannsins byggist á pví að Guð sé til. Guðfræðilegar túlkanir á pessu eru margar en kjarni peirra allra er sá sami: Maðurinn líkist Guði í pví að hann er skynsemisvera með einstaka hæfileika, s.s. sjálfsvitund og ábyrgð. Guðsmyndarlíkingin vísar alltaf til siðferðilegrar hæfni ásamt hæfninni til samfélags við Guð. Sérstaða mannsins er mikil. Einn allra lifandi vera hefur maðurinn hæfileika til djúpstæðrar íhugunar um

\footnotetext{
${ }^{26}$ Luther's Works, American Edition, Fortress Press og Concordia: Philadelphia og St. Louis, 1955-1986, 12, bls. 377-378; 27, bls. 86; 31, bls. 13; 34, bls. 164.

${ }^{27}$ Sama heimild, 35, bls. 370 .
} 
siðferðið og guðdóminn. Í öllu pessu má heyra bergmál af siðfræðilegum hugleiðingum Vilhjálms Árnasonar um mannlega reisn og virðingu. Orðalag heimspekinga og guðfræðinga getur vissulega verið ólíkt en inntakið er mjög líkt: Maðurinn er einstök vera með mikla félagslega og siðferðilega hæfni. Hann er skynsemisvera en í pví felst að hann ber mikla ábyrgð gagnvart samfélagi sínu og samborgunum.

Öll kjarnaatriði pess mannskilnings sem hér hefur verið útskýrður má að sjálfsögðu finna í útleggingum Tómasar frá Akvínó, eins pekktasta guðfræðings miðalda, sem lagði grunninn að skilningi kristinna manna á mannlegri reisn og virðingu, túlkun sem síðari tíma hugsuðir og heimspekingar hafa byggt á og próað áfram. Skynsemi mannsins er hið æðsta og besta einkenni hans, skrifaði Tómas í höfuðverki sínu, Summa Theologica. Ólíkt forngrísku hugsuðunum Aristótelesi og Platón lagði Tómas áherslu á að pað væri Guðs verk að maðurinn ætti hlutdeild í skynseminni. Skynsemi mannsins var óhugsandi í hans hugmyndaheimi nema sem hlutdeild í skynsemi Guðs. Almennt orðað pá á hinn kristni maður að iðka hið góða og réttláta en forðast pað sem illt er og óréttlátt. Hann á að leitast við að stuðla að hamingju annarra og forðast að valda pjáningu. Kristinn mannskilningur, líkt og mannskilningur mannhyggjunnar, byggist á siðferðilegu jafnræði en pað merkir að allir menn hafi sama gildi. Dví fylgir að pað er skylda hvers manns að keppa ekki einungis að pví sem er gott og réttlátt fyrir eigin hag heldur og fyrir aðra. Í Nýja testamentinu má finna boðorðið um náungakærleikann en pað má túlka svo að í pví felist bæði góðvildar- og réttlætisregla. рað má pví orða svo að pað sé skylda mannsins að elska náunga sinn og iðka pá breytni sem leiði gott af sér fyrir fleiri en hann sjálfan. Í öðru lagi má segja að pað sé skylda hvers manns að elska náunga sinn eins og sjálfan sig, p.e. að koma fram við alla sem jafningja. Pannig verða skynsemin, syndin og ábyrgðin ekki aðskilin í kristnum mannskilningi heldur mynda eina heild.

\section{Skömmin — syndin — og sektin}

Að horfast í augu við ófullkomleika sinn og mistök veldur skömm. Flest upplifum við skammartilfinninguna sem eitthvað óæskilegt og vont. Fræðimenn sem fjallað hafa um efnið benda pó á að mikilvægt sé að gera greinarmun á góðri skömm og vondri. Góða skömm megi túlka sem jákvæða, uppbyggilega og verndandi tilfinningu sem hjálpi einstaklingnum að koma auga á og viðurkenna eigin takmarkanir. Annað hugtak yfir sama fyrirbæri er veikleikaskömm en hún er að mati sumra fræðimanna sögð vera grundvöllur pess að manneskjan geti gert sér grein fyrir veikleikum sínum og breyskleika. ${ }^{28}$

Meðal peirra sem hafa velt spurningum um skömmina fyrir sér er geðlæknirinn og sálgreinirinn Johan Beck-Friis en hann bendir einmitt á tvíræoni skammarinnar. ${ }^{29}$ Flestallir segir hann að kannist við skömmina 1 aðstæðum sem peim finnist ópægilegar, t.d. par sem peir séu utanveltu, óvelkomnir, óhreinir eða ófullkomnir. Í slíkum aðstæðum sé skammartilfinningin augljóslega neikvætt fyrirbæri. Í annars konar aðstæðum geti skömmin hins vegar verið jákvæð en pað telur hann vera pegar hún geri

\footnotetext{
${ }^{28}$ Jan-Olav Henriksen og Atle Søvike (ritstj.), Livstolking i skole, kultur og kirke: Festskrift til Peder Gravem, Trondheim: Tapir Akademisk Forlag, 2010, bls. 93.

${ }^{29}$ Johan Beck-Friis, Den nakna skammen: Grund för depression eller väg till ömsesidighet? Stokkhólmi: Natur \& Kultur, 2009, bls. 37.
} 
okkur viðvart eða megni að aftra pví sem sé óæskilegt og óviðeigandi, ýmist fyrir okkur sjálf eða samfélagið. Ályktun Beck-Friis er að hin góða skömm hafi próast sem siðferðilegt mælitæki eða verkfæri í samfélagi manna í aldanna rás og sem slík gegni hún mikilvægu hlutverki, fyrir einstaklinginn og ekki síður samfélagið. Skömmin í jákvæðri merkingu sé nauðsynleg og tilheyri í raun grunnforsendum samfélagsins. Við purfum á skömminni að halda, skrifar Beck-Friis, til pess að mynda góð og réttlát tengsl í samfélaginu og viðhalda peim. ${ }^{30}$

Skömm og sektarkennd tengjast en eru pó ekki sama fyrirbærið! Svo kemst norski guðfræðingurinn Jan-Olav Henriksen að orði í umræðu um skömmina, kosti hennar og galla. Hann bætir við priðju víddinni, syndinni, og segir að sem kristinn guðfræðingur verði ekki hjá pví komist að tala um synd í pessu samhengi. Hugtökin prjú, synd, skömm og sekt, slær hann svo saman í péttan vef par sem um stund er erfitt að átta sig á hvað kemur fyrst og hvað sé afleiðing hvers. Niðurstaða hans er sú að líta beri svo á samkvæmt kristnum skilningi að manneskjan beri ætíð sekt. Sekt hennar sé hluti af hinu synduga, breyska, mannlega eðli. Öll breytni okkar sé meira eða minna ófullkomin. Við purfum að kannast við petta, viðurkenna mistök og vinna með tilfinninguna um hina uppbyggilegu skömm til að bæta okkur.

Hér erum við komin á kunnuglegar slóðir og hittum enn á ný fyrir bað sem ég hef valið að kalla klassískan kristinn mannskilning en grundvallaratriði hans er að maðurinn sé ófullkomin vera og breysk. Hinn ófullkomni maður lifir og breytir andstætt boðum Guðs, skrifar Jan-Olav. ๖að verði að vera forsenda allrar túlkunar á breytni mannsins. Sekt mannsins sé æetíð til staðar, frammi fyrir Guði, samfélaginu og honum sjálfum. Hinum kristna manni eigi að vera pað eiginlegt að upplifa sig sekan, ófullkominn og brotlegan enda hafi Guð gefið honum samvisku til að minna hann á pað. ${ }^{31}$

Við höfum séð að sekt og synd eru guðfræðileg hugtök sem tilheyra kjarnaatriðum kristinnar trúartúlkunar og pað sama gildir um fyrirgefninguna. Guð hefur fyrirgefið mannkyni syndir pess. Sú gjörð merkir pó ekki að við lifum án syndar, pvert á móti. Með tilvísun til skilnings Lúthers á pessu atriði er pað gjarnan orðað svo að við lifum sem syndarar samtímis pví sem við lifum í peirri fullvissu að Guð hafi pegar fyrirgefið okkur syndir, vegna Jesú Krists. Spennan í pessari tvíbentu stöðu mannsins í heiminum hverfur pví aldrei. Við erum syndug og réttlætt samtímis í lífi okkar í heiminum. Баð аð við erum brotlegar manneskjur er mikilvægt að hafa í huga samtímis pví sem við lifum í fullvissunni um kærleika og náð Guðs. Kærleika Guðs og fyrirgefningu ber aldrei að túlka á pann veg að manneskjan beri ekki ábyrgð á breytni sinni. Pvert á móti: okkur ber að axla fulla ábyrgð á breytni okkar í heiminum, góðri jafnt sem slæmri. Við erum ekki fullkomin en prátt fyrir pað megum við kallast Guðs börn. Guð fyrirgefur syndir og pær syndir verðum við að vera fús til að játa. Miskunn og náð Guðs veitist ekki nema að undangenginni iðrun og yfirbót. ${ }^{32}$ En víkjum aftur að skömminni.

\footnotetext{
${ }^{30}$ Sama heimild, bls. 41-42.

31 Jan-Olav Henriksen, Imago Dei: Den teologiska konstruksjonen af menneskets idientitet, 2003, Osló: Gyldendal Akademisk, bls. 19.

32 Ole Modalsli, Korsets gåte: Om Jesu dods betydning, 1987, Osló: Verbum, bls. 95.
} 
Баð hvernig unnið er með tilfinninguna um skömm og sekt getur haft afgerandi pýðingu fyrir pað hvernig sá sem sakaður er um siðferðisbrot bregst við, er niðurstaða rannsókna norska siðfræðingsins Terjes Mesels. ${ }^{33}$ Раð að upplifa hina vondu skömm segir hann að geri oft að verkum að meintur gerandi neiti sekt og forðist par með að taka ábyrgð á breytni sinni. ${ }^{34}$ pess í stað bendi hann á aðra hluti eða annað fólk sem skýringu á pví sem gerðist. Petta virðist mér ákaflega mikilvæg ábending fyrir umræðuefni pessarar greinar. Фað er ekki pægilegt að upplifa skömm. Prátt fyrir pað geta skömmustutilfinningar verið réttlætanlegar og nauðsynlegar, bæði fyrir okkur og samfélagið. Sjálfsskilningur okkar, og par með mannskilningur, má ekki vera fjarri veruleikanum. Flest gerum við mistök, förum yfir mörk, særum fólk og sýnum lítilsvirðingu. Pegar pjónar kirkjunnar eiga í hlut er mikilvægt að kirkjan stígi fram með erindi sitt, sem er kristinn mannskilningur. Hún á að liðsinna peim við að horfast í augu við brotlegt, syndugt manneðli og hvetja til að nýta hina góðu skömm til pess að byggja upp góð tengsl og réttlátt samfélag. Í stað pess að festast í viðjum hinnar vondu skammar sem einangrar pann sem sakaður er um siðferðisbrot parf kirkjan að vinna með hina góðu og uppbyggilegu skömm og hjálpa gerendum siðferðisbrota til að koma til sjálfs sín, kannast við gerðir sínar og axla pá ábyrgð sem Guð hefur gefið sérhverjum manni.

\section{Ályktanir og lokaoro}

Kristinn mannskilningur grundvallast á Biblíunni og kristinni trúarhefð. Hann byggist m.a. á frásögnum Gamla testamentisins par sem lögð er áhersla á að manneskjan sé sköpuð í Guðs mynd en hugmyndin um guðsmyndina hverfist um pað að pað sé Guð sem gefi manninum reisn og tign. Guð elskar alla sköpun sína og allir hafa sama gildi í hans augum, óháð verðleikum og breytni. Petta er sá guðfræðilegi grundvöllur sem kristin kirkja stendur á og jafnframt meginerindi til allra manna, gerenda sem polenda siðferðisbrota.

Fleiri atriði í kristnum mannskilningi mætti nefna pegar kirkjan bregst við slíkum brotum. Eitt peirra allra mikilvægustu er sá skilningur að maðurinn sé tengslavera en samkvæmt kristinni túlkun er honum ætlað pað hlutverk að lifa í samfélagi við aðra, bæði manneskjur og sköpunarverkið í heild sinni, dýrin og lífríkið allt. Guð ávarpar manninn og breytni mannsins má skoða sem andsvar við pví ávarpi. Samkvæmt kristinni túlkun umbreyttist samband Guðs, manns og heims pegar maðurinn reis upp gegn Guði en hugmyndin um syndafallið tjáir pá staðreynd að maðurinn hafi brotið boðorð Guðs og lifi upp frá pví sem ófullkomin vera í ófullkomnum heimi. Gleðitiððindi Nýja testamentisins eru hins vegar pau að Jesús hafi tekið á sig syndir mannkyns og par með lagt grunninn að fyrirgefningu og náð. Klassísk kristin trúartúlkun hverfist um pað að dauði hans og upprisa sé staðfesting á mannhelgi og manngildi allra manna.

Allar manneskjur eiga sömu reisn og tign, óháð breytni sinni og einmitt petta ber okkur að sýna hvert öðru með kærleiksríkri breytni okkar hvert í annars garð. Tengslaeðli manneskjunnar merkir einnig рað að hún er félagsvera og kynvera.

\footnotetext{
33 Terje Mesel, Når noe går galt: Fortellingar om skam og skyld og ansvar i belsetjenesten, Osló: Cappelen Damm Akademisk, 2014. ${ }^{34}$ Hér má hugleiða hvort reynsla Marie Fortune af afneitun gerenda, sem um var rætt framar í greininni, tengist neikvæðri skömm.
} 
Manneskjan laðast að öðrum manneskjum, elskar og práir, gleðst og hryggist. Samtímis pessu er hún sköpuð til ábyrgðar og ber að breyta rétt og réttlátlega gagnvart öðrum manneskjum, sem og öllu sköpunarverki Guðs. Í kristinni túlkun er pað Guð, skaparinn, sem hefur gefið manninum skynsemina og af henni hlýst ábyrgðin, samviskan og möguleikinn að greina gott frá illu og rétt frá röngu. Við erum sköpuð til auðmjúkrar pjónustu og eigum að pjóna Guði í allri okkar breytni. ${ }^{35}$

Samkvæmt kristnum mannskilningi er maðurinn flókin og samsett vera, líkami, andi og sál (1Pess 5.23) ${ }^{36}$ en jafnframt ein heild. Í Biblíunni má víða finna hástemmd orð um manninn (Slm 8.6) en líka raunsærri mynd sem lýsir breyskleika hans og markaleysi (Slm 14.3; Róm 3.10). ${ }^{37}$ Kristin trúarhefð hefur oft túlkað pað svo að í syndafallinu sé sáð fræi illsku í manninn, jafnframt pví að maðurinn beri mynd Guðs í sér. Pannig er kristinn mannskilningur fullur spennu par sem hið góða og illa takast á. Petta merkir að kirkjan verður að vera raunsæ varðandi pað að kristið fólk, eins og annað fólk, sé fært um illa og ranga breytni. Kristnir einstaklingar, eins og aðrir, valda öðrum sárindum og skaða aðra með framkomu sinni, orðum og breytni. Við verðum að vera heiðarleg og taka pað alvarlega pegar upp koma tilvik í kristnu samhengi par sem farið hefur verið yfir siðferðileg mörk. Kristin kirkja á magnað orðfæri um einmitt petta og parf að beita pví pegar pað á við.

Fáir hafa lýst spennunni sem einkennir líf og breytni mannsins betur en Lúther í orðum sínum um að maðurinn sé samtímis réttlættur og syndari. Samkvæmt klassískri, kristinni túlkun endurfæðist kristin manneskja til nýs lífs gegnum skírnina, jafnframt pví sem fræ hins illa eru enn til staðar í henni. Guð býður manninum hjálp í pessum aðstæðum, með orði sínu, kvöldmáltíðinni, skriftum og kristnu samfélagi. Slíkur skilningur á Guði og manni hefur afgerandi afleiðingar. Brot gegn virðingu manneskjunnar er samtímis brot gegn Guði sem hefur skapað sérhverja manneskju. раð er líka brot gegn samfélaginu og gildum pess. Kristið fólk hefur pví ekki aðeins viðmið og gildi samfélagsins að styðjast við heldur einnig hinn kristna mannskilning sem vísar pví á rétta stigu og varnar pví að brjóta gegn samferðafólki sínu.

\footnotetext{
35 Ég tel ekki nauðsynlegt að vísa sérstaklega til fjölda heimilda varðandi hinn kristna mannskilning, jafn pekkt og pessi túlkun er, og ég vel að vísa hér einungis til tveggja greina eftir Björn Björnsson, fyrrverandi prófessor í kristinni siðfræði við Háskóla Íslands: „Biblían og siðfræðin“, Kirkjuritið (sérrit) 1997, bls. 7-11; „Biblían og kristin siðfræði“, Kirkjuritið 1999, bls. 32-37.

36 1Pess 5.23: „En sjálfur friðarins Guð helgi yður algerlega og andi yðar, sál og líkami varðveitist alheil og vammlaus við komu Drottins vors Jesú Krists.“

${ }^{37}$ Slm 8.6: „Đú gerðir hann litlu minni en Guð, krýndir hann hátign og heiðri“; Slm 14.3: „Allir hafa peir vikið af leið, allir eru spilltir, enginn gerir pað sem gott er, ekki neinn.“; Róm 3.10: „Eins og ritað er: Enginn er réttlátur, ekki einn“.
} 